\title{
Perception about Unit Linked Insurance Plan from the Customer at Kotak Mahindra Bank
}

\author{
CS Gowtham Chakravarthi, S. Praveen Kumar
}

\begin{abstract}
The examination proposed to be directed at Kotak Mahindra Bank is a logical and unmistakable kind of research, utilizing both essential and auxiliary information and Statistical apparatuses like Simple rate investigation, positioning technique and chi-square examination. Based on criticism through poll, meeting and perception strategy, we discover the discernment see about the insurance agency's working style and administrations offered is very viable, Management of Kotak Mahindra Bank is always trying endeavors to make the organization the best work environment for level. As they are proportions of people mental cosmetics and character and in that capacity are amazingly ground-breaking instruments as discover from our relative examination results. A Unit Link Insurance Plan is fundamentally a mix of protection just as venture. In Unit Linked Insurance Plans (ULIP), the speculations made are liable to dangers related with the capital markets. This venture chance in speculation portfolio is borne by the arrangement holder. Along these lines, you should settle on your venture decision subsequent to thinking about your hazard craving and needs. The aftereffect of this exploration would assist the organization with having a superior comprehension about the customer's observation towards extra security.
\end{abstract}

Keywords: Unit Link Insurance Plan, Speculation Portfolio, Auxilary Information

\section{INTRODUCTION}

"The Business of Insurance is identified with the assurance of the monetary estimations of the benefits".

Every individual will in general extra to shield him from risks or events of future. Security is one sort of speculation subsidizes where in people endeavor to promise themselves against risks or vulnerabilities of future. It is affirmation against perils or events or hardships. People can save their pay either in the structure gold, fixed assets like property or in banking and securities[1],[3],[5]. The entire save assets of people of a country speak to net private speculation reserves. In India, disregarding the way that hold supports rate is high anyway people like to place either in gold or fixed assets so they can make money out of it. Consequently assurance portion is up 'til now unfamiliar in India[2 ],[4],[6].

Customer acknowledgment applies the possibility of unmistakable perception to displaying and advancing. So also as substantial perception relates to how individuals see and strategy material enhancements through their five

Revised Manuscript Received on July 22, 2019.

Mr. CS Gowtham Chakravarthi, Department of MBA, Bharath Institute of Higher Education and Research, Chennai, India.

Email: chakravins@gmail.com

Dr. S. Praveen Kumar, Department of MBA, Bharath Institute of Higher Education and Research, Chennai, India.

Email: praveenkumar.mba@bharathuniv.ac.in identifies, customer acumen identifies with how individuals structure suppositions about associations and the item they offer through the purchases they make. Merchants apply purchaser insight theory to choose how their customers see them. They furthermore use buyer acumen speculation to make exhibiting and publicizing frameworks proposed to hold current customers - and attract new ones[7],[9],[11].

\section{RESEARCH METHODOLOGY}

\section{STATEMENT OF THE PROBLEM:}

A study on Perception about Unit Linked Insurance Plan from the Customer at Kotak Mahindra Bank

\section{Sampling Method}

The researcher has been adopted to select simple random sampling method

\section{Sample size}

The researcher has selected 200 clients of Kotak Mahindra Bank

\section{ANALYSIS}

\section{A. Simple percentage analysis:}

Basic rate examination alludes to a proportion. With the assistance of total figures it will be hard to interpretive any significance from the gathered information, yet when rates are discovered then it turns out to be anything but difficult to locate the relative distinction between two are more characteristics[8],[10],[12].

No. Of respondents

Percentage $=$ x 100

Total number of respondents

\section{B. Weighted Average}

The from weighted normal for the most part report to a weighted math mean yet weighted refrains of different methods can likewise be determined, for example, the weighted Geometric mean weighted consonant mean.

Weighted Average $=\sum \mathrm{Wx} / \sum \mathrm{x}$

(W) Weight

(X) No. of respondents

\section{One Way Anova}

Single direction investigation of change is a method used to look at methods for at least two examples. This strategy can be utilized distinctly for numerical information. The ANOVA tests the invalid speculation that examples in at least two gatherings are drawn from populaces with a similar 
mean qualities[13], [15],[17].

Table - 1 Plan for Financial Goals

\begin{tabular}{|l|l|l|}
\hline PARTICULARS & FREQUENCY & PERCENTAGE \\
\hline Marriage & 16 & 7 \\
\hline Child education & 22 & $\mathbf{1 1}$ \\
\hline Tax savings & 67 & $\mathbf{3 4}$ \\
\hline Retirement & 74 & $\mathbf{3 7}$ \\
\hline Any other & 21 & $\mathbf{1 1}$ \\
\hline TOTAL & 200 & 100 \\
\hline
\end{tabular}

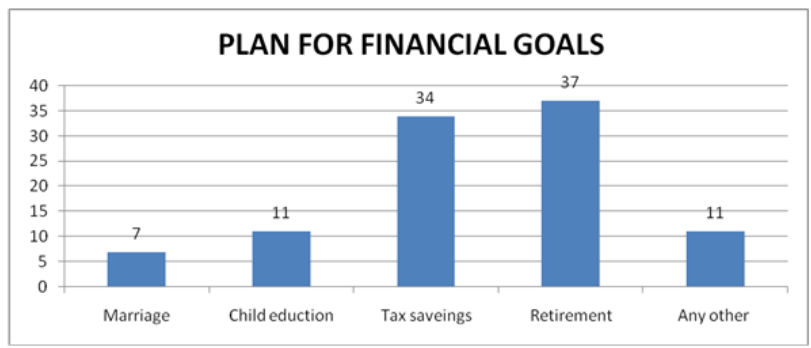

Figure - 1 Plan for Financial Goals

Table - 2 Duration to Use Ulip

\begin{tabular}{|l|l|l|}
\hline PARTICULARS & FREQUENCY & PERCENTAGE \\
\hline Less than 1 year & 52 & 26 \\
\hline $1-3$ years & 51 & 24 \\
\hline 3-5 years & 41 & 21 \\
\hline $5-7$ years & 23 & 12 \\
\hline More than 7 years & 33 & 17 \\
\hline TOTAL & 200 & 100 \\
\hline
\end{tabular}

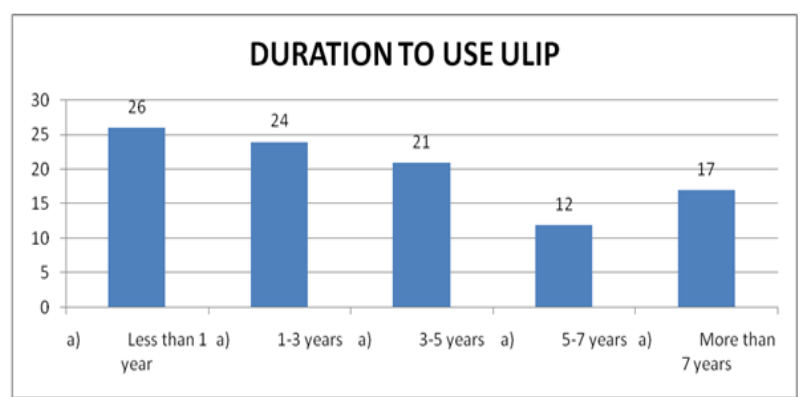

Figure - 2 Duration to Use Ulip

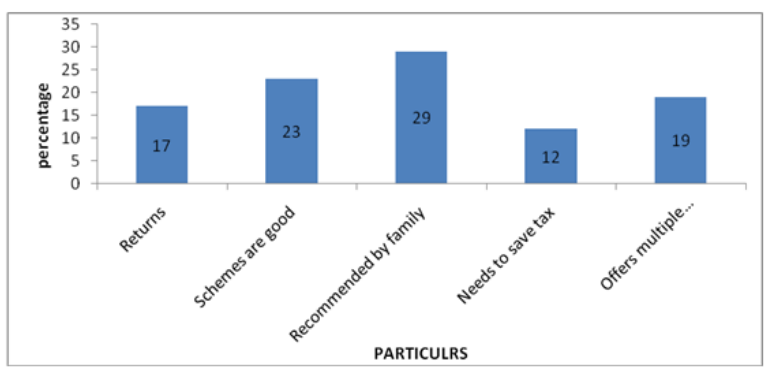

Figure - 3 Reasons For Investing In Ulips

Table - 3 The Premium Amount To Be Paid In Ulip Of Kotak Mahindra Bank

\begin{tabular}{|l|l|l|}
\hline PARTICULARS & FREQUENCY & PERCENTAGE \\
\hline Low & 26 & 13 \\
\hline Very low & 34 & 17 \\
\hline Average & 56 & 28 \\
\hline High & 22 & 11 \\
\hline Very high & 62 & 31 \\
\hline Total & 200 & 100 \\
\hline
\end{tabular}

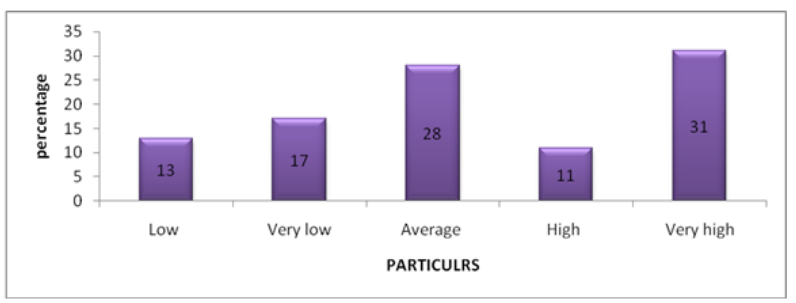

Figure -4 The Premium Amount To Be Paid In Ulip Of Kotak Mahindra Bank

Table - 4 The Returns In Ulip Of Kotak Mahindra Bank

\begin{tabular}{|l|l|l|}
\hline PARTICULARS & FREQUENCY & PERCENTAGE \\
\hline Low & 46 & 23 \\
\hline Very low & 24 & 12 \\
\hline Average & 32 & 16 \\
\hline High & 54 & 27 \\
\hline Very high & 44 & 22 \\
\hline Total & 200 & 100 \\
\hline
\end{tabular}

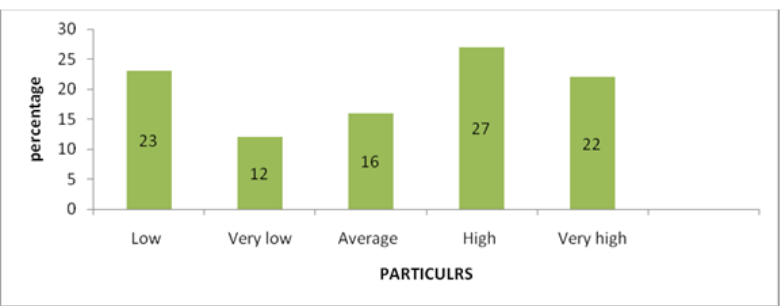

Figure - 5 The Returns In Ulip Of Kotak Mahindra Bank

Table-5 Units Allocated In Ulip Of Kotak Mahindra Bank 


\begin{tabular}{|l|l|l|}
\hline PARTICULARS & FREQUENCY & PERCENTAGE \\
\hline Low & 26 & 13 \\
\hline Very low & 48 & 24 \\
\hline Average & 66 & 33 \\
\hline High & 42 & 21 \\
\hline Very high & 18 & 9 \\
\hline Total & 200 & 100 \\
\hline
\end{tabular}

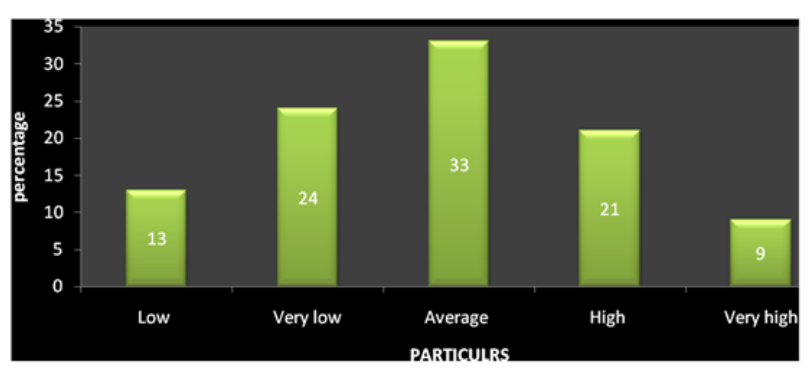

Figure-6 Units Allocated In Ulip Of Kotak Mahindra Bank

Table - 6 The Risk Associated With Ulip Of Kotak Mahindra Bank

\begin{tabular}{|l|l|l|}
\hline PARTICULARS & FREQUENCY & PERCENTAGE \\
\hline Low risk & 44 & 22 \\
\hline Very low risk & 36 & 18 \\
\hline Average risk & 68 & 34 \\
\hline High risk & 29 & 14 \\
\hline Very high risk & 23 & 12 \\
\hline Total & 200 & 100 \\
\hline
\end{tabular}

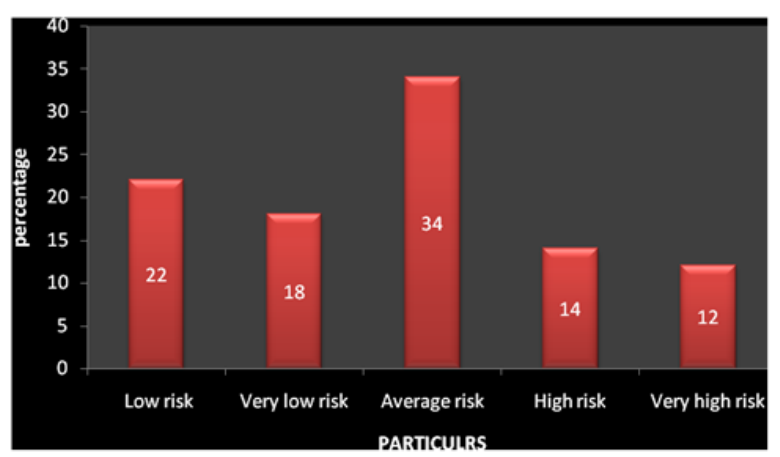

Figure - 7 The Risk Associated With Ulip Of Kotak Mahindra Bank

\section{Descriptives}

The Returns In Ulip Of Kotak Mahindra Bank

\begin{tabular}{|c|c|c|c|c|c|c|c|c|}
\hline & \multirow[b]{2}{*}{$\mathrm{N}$} & \multirow[b]{2}{*}{ Mean } & \multirow{2}{*}{$\begin{array}{l}\text { Std. } \\
\text { Deviatio } \\
\text { n }\end{array}$} & \multirow[b]{2}{*}{$\begin{array}{l}\text { Std. } \\
\text { Error }\end{array}$} & \multicolumn{2}{|c|}{ 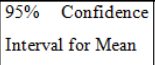 } & \multirow[b]{2}{*}{ Minimum } & \multirow[b]{2}{*}{ Maximum } \\
\hline & & & & & $\begin{array}{l}\text { Lower } \\
\text { Bound }\end{array}$ & $\begin{array}{l}\text { Upper } \\
\text { Bound }\end{array}$ & & \\
\hline Returns & 41 & 1.00 & .000 & .000 & 1.00 & 1.00 & 1 & 1 \\
\hline Schemes are good & 46 & 1.96 & 698 & .103 & 1.75 & 2.16 & 1 & 3 \\
\hline $\begin{array}{l}\text { Recommended by } \\
\text { family }\end{array}$ & 58 & 3.62 & .489 & .064 & 3.49 & 3.75 & 3 & 4 \\
\hline Needs to save tax & 23 & 4.22 & .422 & .088 & 4.04 & 4.40 & 4 & 5 \\
\hline $\begin{array}{l}\text { Offers } \\
\text { benefits, } \\
\text { investment+insurance } \\
\text { +tax saving }\end{array}$ & 32 & 5.00 & .000 & .000 & 5.00 & 5.00 & 5 & 5 \\
\hline
\end{tabular}

Tabulated value $=\mathbf{2 . 6 0}$

Calculated value $=492.052$

$\mathrm{F}=\mathrm{F}$ cal $>\mathrm{F}$ tab $\quad \mathrm{F}=492.052>2.60$

Hence, the Alternate hypothesis [H1] is accepted.

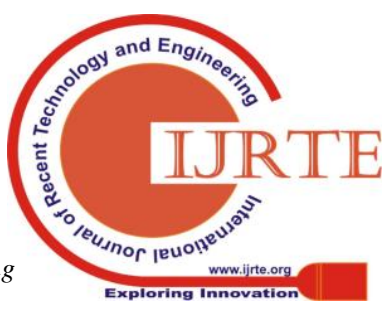




\section{Perception about Unit Linked Insurance Plan From The Customer at Kotak Mahindra Bank}

\section{Inference:}

The calculated value of $F$ is greater than the tabulated value. Hence, we reject the null hypothesis and conclude that there is a significance difference the reasons for investing in ulips and the returns in ulip of Kotak Mahindra Bank

\section{Weighted Average Method}

The weighted moving average is obtained on dividing the weighted moving total by the sum of the weight.

$=\Sigma w i x i / \Sigma x i$

A weight average with appropriate weight is generally used when the moving average are strongly affected by extreme value.

Table - 6 Satisfaction Level Of Current Supervision System

\begin{tabular}{|l|l|l|l|}
\hline Particulars & F & W & WF \\
\hline Returns & 34 & 4 & 136 \\
\hline Schemes are good & 46 & 2 & 92 \\
\hline Recommended by family & 58 & 1 & 58 \\
\hline Needs to save tax & 24 & 5 & 120 \\
\hline $\begin{array}{l}\text { Offers multiple benefits, like investment } \\
\text { + insurance + tax saving }\end{array}$ & 38 & 3 & 114 \\
\hline TOTAL & $\mathbf{2 0 0}$ & & $\mathbf{5 2 0}$ \\
\hline
\end{tabular}

Weighted average $=\sum w f / \sum f$

$$
\begin{aligned}
& =520 / 200 \\
& =2.6=3
\end{aligned}
$$

Inference:

From above table, it can be inferred that most of the respondents are satisfied for the offers multiple benefits, like investment + insurance + tax saving.

\section{Correlation Coefficient}

\section{Null hypothesis (H0):}

There is a negative significance between the reasons for investing in ulips and the returns in ulip of Kotak Mahindra Bank

\section{Alternate hypothesis (H1):}

There is positive significance between the reasons for investing in ulips and the returns in ulip of Kotak Mahindra Bank

Table - 7 The Equipment To Measure The Correlation Coefficient Between Investing In Ulips And Returns In Ulip Are As Follows

\begin{tabular}{|l|l|l|l|l|l|l|}
\hline$\underline{\mathbf{X}}$ & $\underline{\mathbf{X}-\mathbf{X}^{-}(\mathbf{x})}$ & $\underline{\underline{\mathbf{2}}}^{\mathbf{2}}$ & $\underline{\mathbf{Y}}$ & $\underline{\mathbf{Y}-\mathbf{Y}^{-}(\mathbf{y})}$ & $\mathbf{y}^{\mathbf{2}}$ & $\underline{\mathbf{x}}$ \\
\hline 64 & -3 & 9 & 66 & -2 & 4 & 6 \\
\hline 65 & -2 & 4 & 67 & -1 & 1 & 2 \\
\hline 66 & -1 & 1 & 65 & -3 & 9 & 3 \\
\hline 67 & 0 & 0 & 68 & 0 & 0 & 0 \\
\hline 68 & 1 & 1 & 70 & 2 & 4 & 2 \\
\hline 69 & 2 & 4 & 68 & 0 & 0 & 0 \\
\hline 70 & 3 & 9 & 72 & 4 & 16 & 12 \\
\hline & & $\sum \mathrm{x}^{2} 28$ & & & $\sum \mathrm{y}^{2} 34$ & $\sum \mathrm{xy} 25$ \\
\hline
\end{tabular}

$$
\begin{aligned}
\text { Correlation }(\mathrm{r})=\sum \mathrm{xy} / \sqrt{ } & \sum x^{2} X \Sigma y^{2} \\
& =25 / 28 \times 34 \\
& =25 / 30.85 \\
& =0.810
\end{aligned}
$$

As the correlation value is less than 1, there has positive significance between both. In other way, we can said that here we can accept alternate hypothesis (H1).

\section{RESULTS}

1. Most of the respondents are in the age bunch between 51\& Above

2. $52 \%$ of the respondents are Salaried

3. Employees Most of the workers are gaining 3 lakh-5 lakh

4. Most of the respondents feel that the most significant factor they look before picking a venture is to expand their riches

$5.38 \%$ of the respondents are liked to put resources into ULIP [14],[16], [18]

6. Most of the representatives know data about ULIP through Television.

7. $28 \%$ of the respondents discover best for ULIPS in Kotak Mahindra Bank

8. $40 \%$ of the respondents are plan to put resources into ULIP for 10-20 years.

9. Most of the respondents like to put resources into ULIPS for the Investment.

10. Most of the respondent's principle budgetary objective is for retirement life

11. $26 \%$ of the respondents are taken ULIP for Less than 1 year

12. Most of the respondents are prescribed by family and companions for putting resources into ULIPS of Kotak Mahindra Bank .

13. Most of the respondents feel that the excellent add up to be paid in ULIPS of Kotak Mahindra Bank is high.

14. Most of the respondents feel that the profits in ULIPS of Kotak Mahindra Bank are high[19],[21],[23]

15. Most of the respondents apportion normal number of units in ULIP of Kotak Mahindra Bank

16. Most of the respondents feel that the hazard related with ULIP of Kotak Mahindra Bank is high.

17. Most of the respondents have low plans with ulip of Kotak Mahindra Bank.

18. Most of the respondents are exceedingly adaptability with ulip of Kotak Mahindra Bank . 
choices moreover

19. Most of the respondents feel that the straightforwardness with ulip of Kotak Mahindra Bank is normal[20],[22],[24].

20. Most of the respondents feel normal about the month to month charges in ulip of Kotak Mahindra Bank .

21. More respondents appraised High rate for the organization charges in ULIP.

22. Most of the respondents appraised high rate for give up charges in ULIP.

23. Most of the respondents are happy with the ULIP.

24. More respondents appraised high rate for ULIP's store the executives

25. Most of the respondents feel that the straightforwardness with ulip of Kotak Mahindra Bank is normal.

\section{V.DISCUSSIONS}

1. The charges like organization charges, give up charges and store the board rate are appraised high. This may make a negative effect to put resources into this arrangement. The organization can make a few adjustments in the charges to get more financial specialists

2. The straightforwardness with ulip of Kotak Mahindra Bank is normal which might be a negative effect for the financial specialists. The organization is proposed to keep the records of the clients as exceptionally shrouded [25],[27],[29]

3. The hazard related with ULIP of Kotak Mahindra Bank is high a direct result of the offer value developments. The organization can make some mindfulness program about their arrangements to pull in clients and furthermore present a few plans with okay

4. Only $38 \%$ of the respondents are wanted to put resources into ULIP and $28 \%$ of the respondents discover best for ULIPS in Kotak Mahindra Bank . Mindfulness program about the upsides of the ULIPS will assist the organization with getting more speculators

5. Although the profits in ULIPS of Kotak Mahindra Bank are high, the hazard related with ULIP of Kotak Mahindra Bank is likewise exceptionally high[26],[28],[30].

6. Most of the respondents are picking the retirement plan. The organization can give a few ideas for different alternatives like Marriage, Child training, Tax reserve funds and different designs to get more financial specialists in these

\section{CONCLUSION}

A A Unit Link Insurance Plan is essentially a mix of protection just as speculation. In Unit Linked Insurance Plans (ULIP), the speculations made are liable to dangers related with the capital markets. This venture chance in speculation portfolio is borne by the arrangement holder. Subsequently, you should settle on your venture decision in the wake of thinking about your hazard hunger and needs[31],[33].

Based on input through poll, meeting and perception strategy, we discover the observation see about the insurance agency's working style and administrations offered is very powerful, Management of Kotak Mahindra Bank is continually trying endeavors to make the organization the best work environment for level. As they are proportions of people mental cosmetics and character and in that capacity are amazingly ground-breaking instruments as discover from our relative investigation results.

\section{REFERENCES}

1) BharthVajan R., Ramachandran S.,Psychographic dimensions of training,2016,International Journal of Pharmacy and Technology,V-8,I-4,P-23727-23729

2) Balakrishnan P., Bharthvajan R.,A study on human resource planning in hospitals in Chennai City,2014,International Journal of Applied Engineering Research,V-9,I-22,P-7503-7507

3) Priyadarsini P., Bharthvajan R.,Role of emotional intelligence training programme in reducing the stress of the nurses,2014,International Journal of Applied Engineering Research,V-9,I-22,P-7411-7421

4) Kerinab Beenu G., Bharthvajan R.,Empirical analysis on the cosmetic buying behavior of young women in South India,2014,International Journal of Applied Engineering Research,V-9,I-22,P-7361-7366

5) Balakrishnan P., Bharthvajan R.,Whistling in the wind,2014,International Journal of Applied Engineering Research,V-9,I-22,P-7586-7593

6) Krishnan B., Peter M.,Health hazards of Indian Bpo employee-an alarming issue,2014,International Journal of Applied Engineering Research,V-9,I-22,P-7336-7341

7) Kerinab Beenu G.H., Peter M.,Role of insurance in economic development,2014,International Journal of Applied Engineering Research,V-9,I-22,P-7532-7539

8) Balakrishnan P., Peter M., Priyadarsini P.,Efficiency of safety measures for wellbeing of employees in manufacturing industry,2014,International Journal of Applied Engineering Research,V-9,I-22,P-7376-7382

9) Anbarasi M., Praveen Kumar S.,Online sales promotions of herbal products and its effectiveness towards tanisha.com,2019,Indian Journal of Public Health Research and Development,V-10,I-1,P-195-200

10) Anbarasi M., Praveen Kumar S.,Various online marketing and promotions strategies to improve the validation towards the organic products in the pharmaceutical sectors,2019,Indian Journal of Public Health Research and Development, V-10,I-1,P-263-269

11) Loganathan R., Praveen Kumar S.,Grievance handling a key factor for solving issues of employees in an organization,2014,International Journal of Applied Engineering Research,V-9,I-22,P-7483-7491

12) Loganathan R., Praveen Kumar S.,Study on preference of private label brands in super and Hypermarkets,2014,International Journal of Applied Engineering Research,V-9,I-22,P-7327-7335

13) Smitha M., Praveen Kumar S.,Understanding stress and its managementamong the nurses in Chennai city,2014,International Journal of Applied Engineering Research,V-9,I-22,P-7560-7565

14) Kerinab Beenu G.H., Praveen Kumar S.,A study on the investment behavior of Chennai investors in mutual fund schemes,2014,International Journal of Applied Engineering Research,V-9,I-22,P-7520-7525

15) Loganathan R., Praveen Kumar S.,Retention strategies key for organizational productivity,2014,International Journal of Applied Engineering Research,V-9,I-22,P-7443-7447

16) Pavithra J., Ganesan M., Brindha G.,State wise analysis of microfinance sector in India,2016,International Journal of Pharmacy

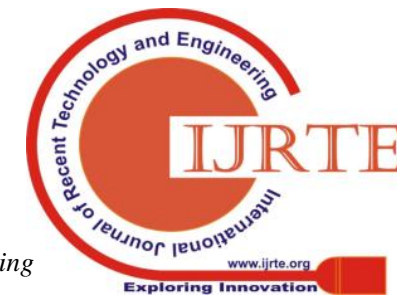


Technology,V-8,I-4,P-23417-23432

17) Pavithra J., Ganesan M.,A comparative study on microfinance in India and abroad,2016,International Journal of Applied Business and Economic Research,V-14,I-8,P-5471-5476

18) Pavithra J., Ganesan M.,A study on awareness and impact of micro-financial schemes,2016,International Journal of Applied Business and Economic Research,V-14,I-8,P-5449-5460

19) Senthilmurugan P., Pavithra J.,Consumer preference towards organised retailing with reference to Big Bazaar,2014,International Journal of Applied Engineering Research,V-9,I-22,P-7469-7475

20) Senthilmurugan P., Pavithra J.,Implication of social media marketing in growing healthcare industry,2014,International Journal of Applied Engineering Research,V-9,I-22,P-7448-7456

21) Loganathan R., Pavithra J.,Consumer perception towards private label brand over other brands in super markets and hypermarkets,2014,International Journal of Applied Engineering Research,V-9,I-22,P-7355-7360

22) Kerinab Beenu G., Pavithra J.,Tradeâ€"off between liquidity and profitability in logistics industry,2014,International Journal of Applied Engineering Research,V-9,I-22,P-7398-7401

23) Kerinab Beenu G., Pavithra J.,A study on the prospective consumerâ $€^{\mathrm{TM}_{\mathrm{S}}}$ perception towards utility cars in Chennai city,2014,International Journal of Applied Engineering Research,V-9,I-22,P-7526-7531

24) Pavithra J., Dilli Babu P., Ambuli T.V.,A study on budgetary control at Maruti Service Masters, Chennai,2014,International Journal of Applied Business and Economic Research,V-12,I-2,P-151-161

25) Pavithra J., Dilli Babu P., Ambuli T.V.,A study on customer satisfaction of retro Garments Pvt Ltd, Chennai,2014,International Journal of Applied Business and Economic Research,V-12,I-2,P-381-391

26) Kerinab Beenu G.H., Pavithra J., Senthilmurugan P.,A study on the influence of promotional activities for TATA ARIA among consumers in Chennai,2014,International Journal of Applied Engineering Research,V-9,I-22,P-7572-7578

27) Vijayaragavan S.P.,An investigative expert that's general FBG sensors,International Journal of Mechanical Engineering and Technology,V-8,I-8,PP-1500-1505,Y-2017

28) Vijayaragavan S.P.,Equalization routing protocol for Wi-Fi sensor strategy,International Journal of Mechanical Engineering and Technology,V-8,I-8,PP-1662-1666,Y-2017

29) Karthik B., Kiran Kumar T.V.U., Vijayaragavan P., Bharath Kumaran E.,Design of a digital PLL using $0.35 \hat{1}^{1} / 4 \mathrm{~m}$ CMOS technology,Middle East Journal of Scientific Research,V-18,I-12,PP-1803-1806,Y-2013

30) Kanniga E., Selvaramarathnam K., Sundararajan M.,Kandigital bike operating system,Middle - East Journal of Scientific Research,V

31) Jasmin M., Vigneshwaran T., Beulah Hemalatha S.,Design of power aware on chip embedded memory based FSM encoding in FPGA,International Journal of Applied Engineering Research,V-10,I-2,PP-4487-4496,Y-2015

32) Jasmin M.,Optimization techniques for low power VLSI circuits,Middle East Journal of Scientific Research,V-20,I-9,PP-1082-1087,Y-2014

33) Jasmin M., Vigneswaran T.,Fuzzy controller for error control of on - Chip communication,2017 International Conference on Algorithms, Methodology, Models and Applications in Emerging Technologies, ICAMMAET 2017,V-2017-January,I-,PP-1-5,Y-2017

\section{AUTHORS PROFILE}

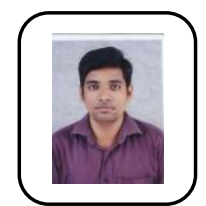

Mr. CS Gowtham Chakravarthi Assistant Professor, Department of MBA, Bharath Institute of Higher Education and Research, Chennai, India.

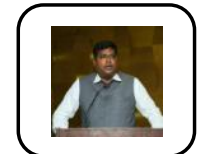

Dr. S. Praveen Kumar, Professor, Department of MBA, Bharath Institute of Higher Education and Research, Chennai, India. 